\title{
Ear Ointment Dosage Form
}

National Cancer Institute

\section{Source}

National Cancer Institute. Ear Ointment Dosage Form. NCI Thesaurus. Code C149457.

Semi-solid single-dose or multidose preparation consisting of an ointment intended for application to the external auditory meatus, if necessary by means of a tampon impregnated with the preparation. 